\title{
Pancreatic Elastase Measurement
}

National Cancer Institute

\section{Source}

National Cancer Institute. Pancreatic Elastase Measurement. NCI Thesaurus. Code C82028.

The determination of the amount of pancreatic elastase present in a sample. 